Advances in Gene Technology: The Genome and Beyond -

Structural Biology for Medicine (Proceedings of the 2002 Miami

Nature Biotechnology Winter Symposium)

TheScientificWorld 2002, 2(S2), 36-38

ISSN 1532-2246; DOI 10.1100/tsw.2002.19

\title{
EXTRACTION AND PURIFICATION OF PROTEINS FROM E. coli WITHOUT HARVESTING CELLS
}

\author{
Anthony Grabski, Don Drott, Mark Handley, Mark Mehler, and Robert Novy \\ Novagen, Inc., 601 Science Drive, Madison, WI 53711 \\ tony.grabski@novagen.com
}

INTRODUCTION. Extraction and separation of foreign proteins expressed in E. coli commonly employs multistep fractionation procedures combining centrifugation, mechanical disruption, volume reduction, filtration, and finally capture and recovery in order to separate cells from culture media and purify the target protein from the cell extracts[1,2]. These methods are not amenable to rapid high throughput (HT) purification of thousands of proteins. We demonstrate here a HT-compatible reagent, PopCulture ${ }^{\mathrm{TM}}$, and associated method that eliminate the necessity for multiple mechanical fractionation procedures. The entire culturing, extraction, and purification can be achieved in the original culture tube or multiwell plate. This "in-media" protein purification procedure may be adapted to high throughput robotic processing of samples for proteomics research and any application that would benefit from the increased speed and convenience it provides.

METHOD. Protein is isolated by culturing cells in liquid media under conditions for optimal target protein expression, chemically lysing the cells directly in their liquid media with a concentrated mixture of specialized detergents and buffer (*PopCulture ${ }^{\mathrm{TM}}$ Reagent), reduction of the extract's viscosity by the addition of *Benzonase ${ }^{\circledR}$ nuclease and *lysozyme, capturing the target protein by adsorption to an *affinity matrix, washing the capture matrix-target protein complex to remove spent culture media and unwanted cellular contaminants, and elution of the purified protein from the adsorptive matrix (*Novagen Inc., Madison, WI).

RESULTS. We have employed the PopCulture Reagent and protocol to purify a GST Tag ${ }^{\mathrm{TM}} / \mathrm{His}$ Tag ${ }^{\circledR}$ fusion protein using immobilized glutathione (GST-Bind Resins) or immobilized metal chelation (IMAC; His-Bind ${ }^{\circledR}$ Resins). The results are summarized in Table 1 and Figs. 1 and 2. 


\section{Table I. Purification of His•Tag ${ }^{\circledR}$ GST}

expressed in $E$. coli

\begin{tabular}{lcc} 
Purification Method & Yield $^{\mathbf{1}}$ & Purity $^{2}$ \\
\hline Standard His•Bind $^{\circledR}$ & 74 & 83 \\
PopCulture $^{\mathrm{TM}} \mathrm{His} \bullet$ Bind & 111 & 89 \\
PopCulture Ni-NTA His•Bind $^{2}$ & 170 & 85 \\
PopCulture His•Bind Magnetic $^{3}$ & 128 & 94 \\
\hline Standard GST•Bind & & 92 \\
PopCulture GST•Bind & 42 & 92 \\
PopCulture GST•Bind Magnetic $^{3}$ & 40 & 90 \\
\hline
\end{tabular}

1. Yield in micrograms of target protein purified per ml of culture, as determined by BCA protein assay.

2. \% purity determined by scanning densitometry of Coomassie blue stained SDS polyacrylamide gels.

3. Data represent the average of 8 separate wells processed in parallel.

Figure 1. IMAC purification of a His॰Tag fusion protein from $E$. coli total culture extracts A. Batch/column purification B. Magnetic purification
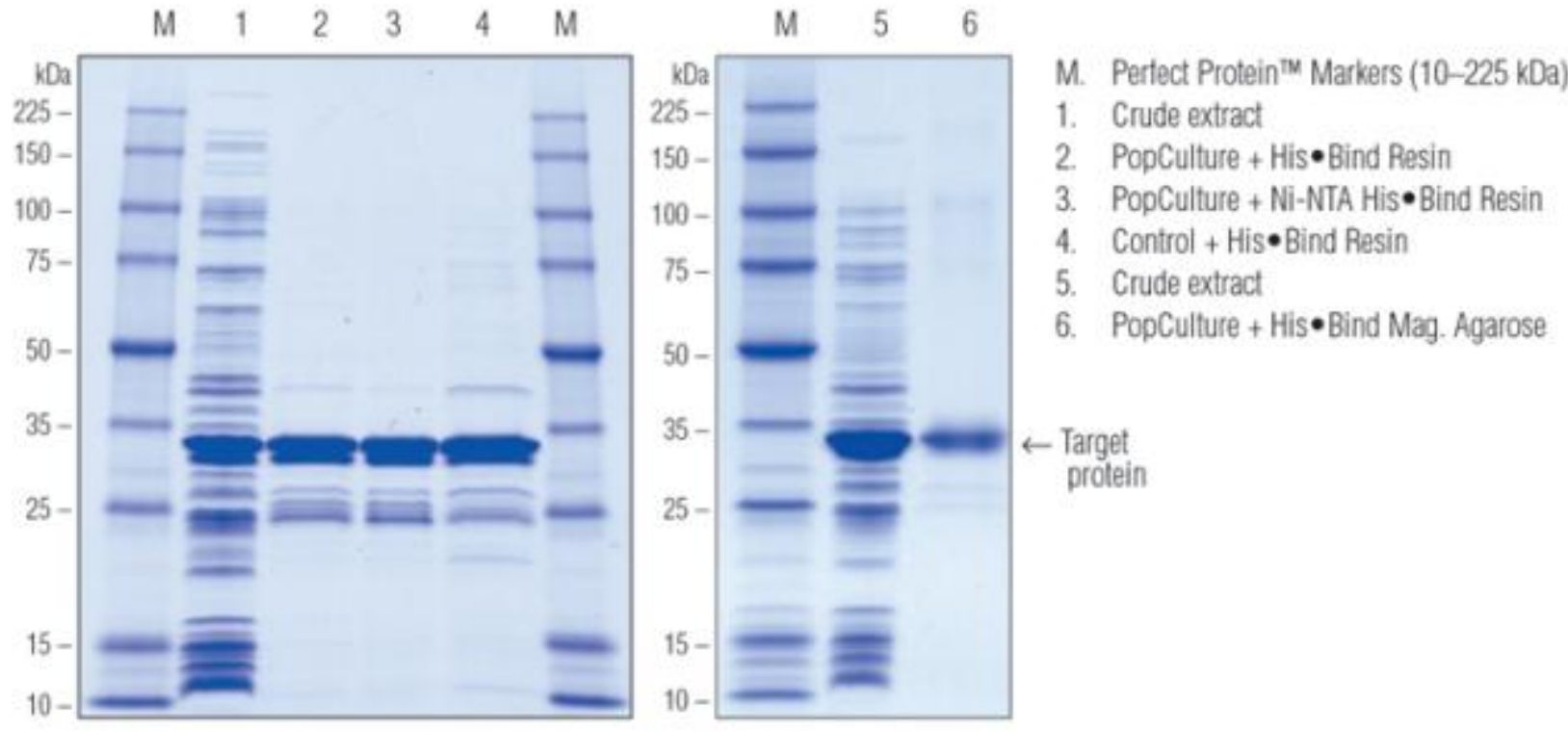
Figure 2. GST•Bind purification of a GST fusion protein from E. coli total culture extracts A. Batch/column purification B. Magnetic purification
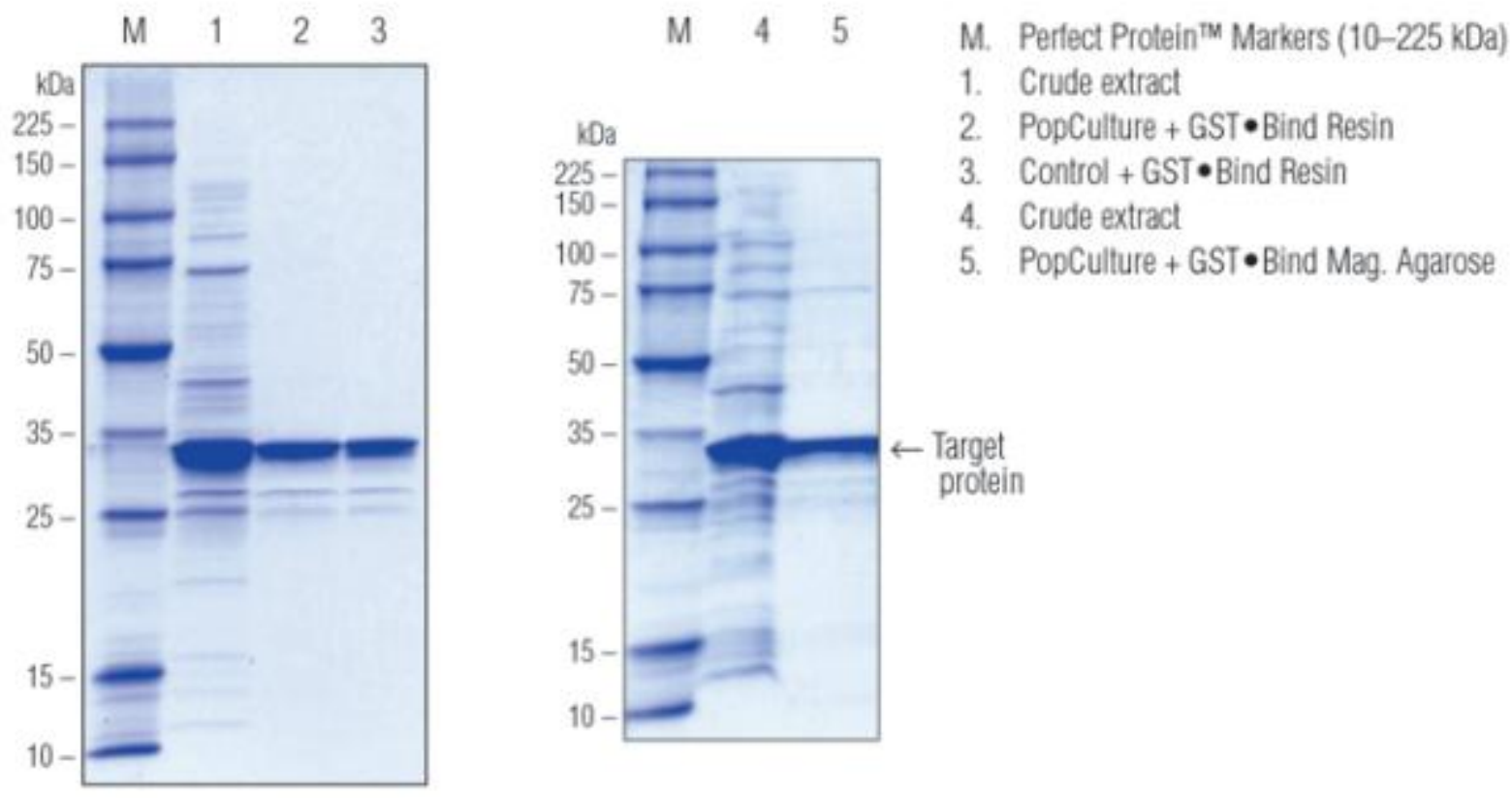

DISCUSSION. Extraction and purification of E. coli expressed proteins has been simplified through the application of specialized reagents that eliminate the need for mechanical disruption of cells[3]. This led us to consider the possibility that a concentrated formulation of detergents could achieve similar performance when added directly to unprocessed cultures, eliminating the need to collect the cells. The examples here demonstrate that direct lysis and affinity purification of total culture lysates can produce high yields of target proteins with purity and quality similar to conventionally purified preparations.

\section{REFERENCES}

1. Burgess, R.R., Ed. (1987) Protein Purification: Micro to Macro. Alan R. Liss, New York.

2. $\quad$ Deutscher, M.P., Ed. (1990) Methods in Enzymology 182. Guide to Protein Purification. Academic Press, New York.

3. $\quad$ Grabski, A.C., McCormick, M., and Mierendorf, R. (1999) inNovations 10, $17-$ 19. 

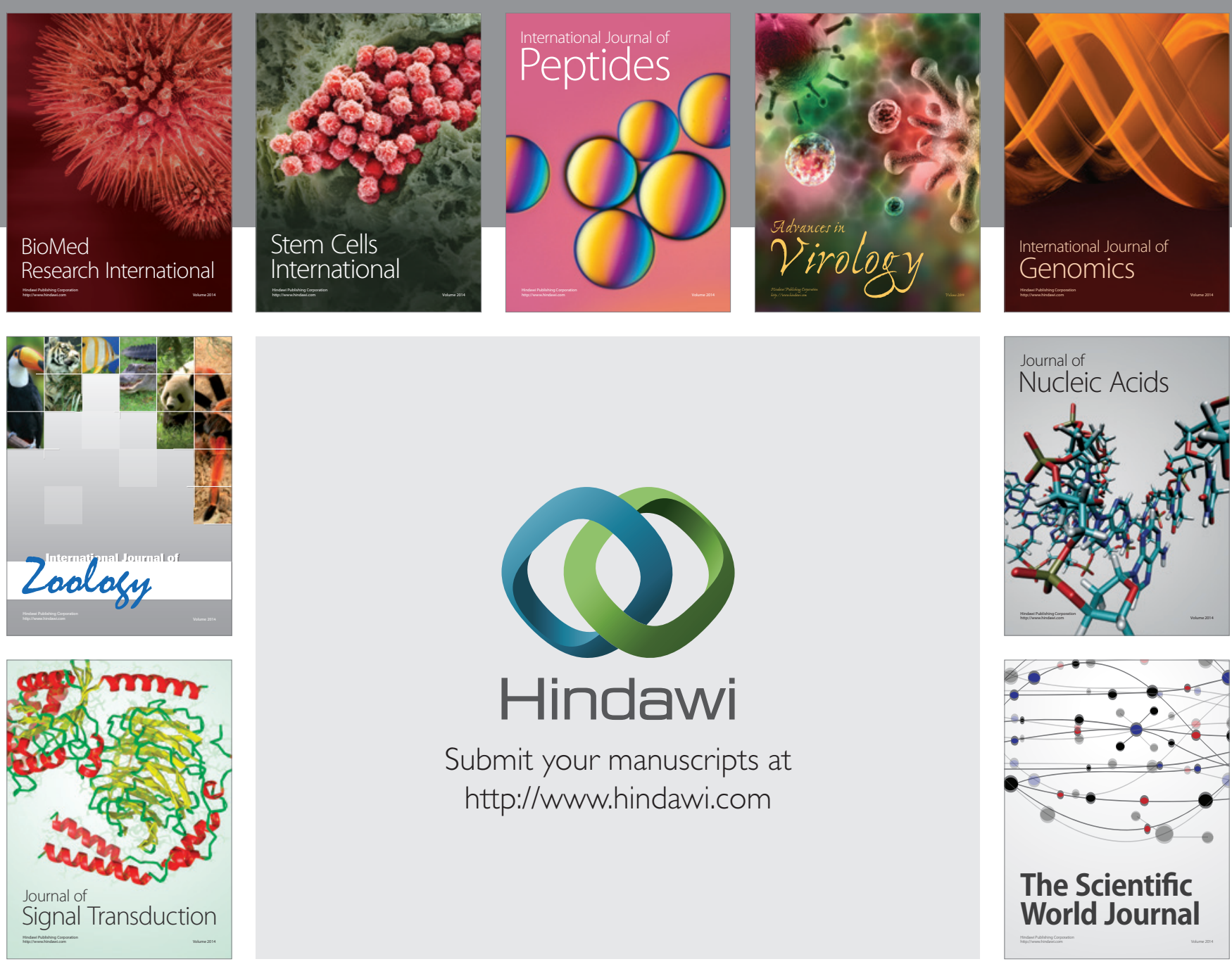

Submit your manuscripts at

http://www.hindawi.com
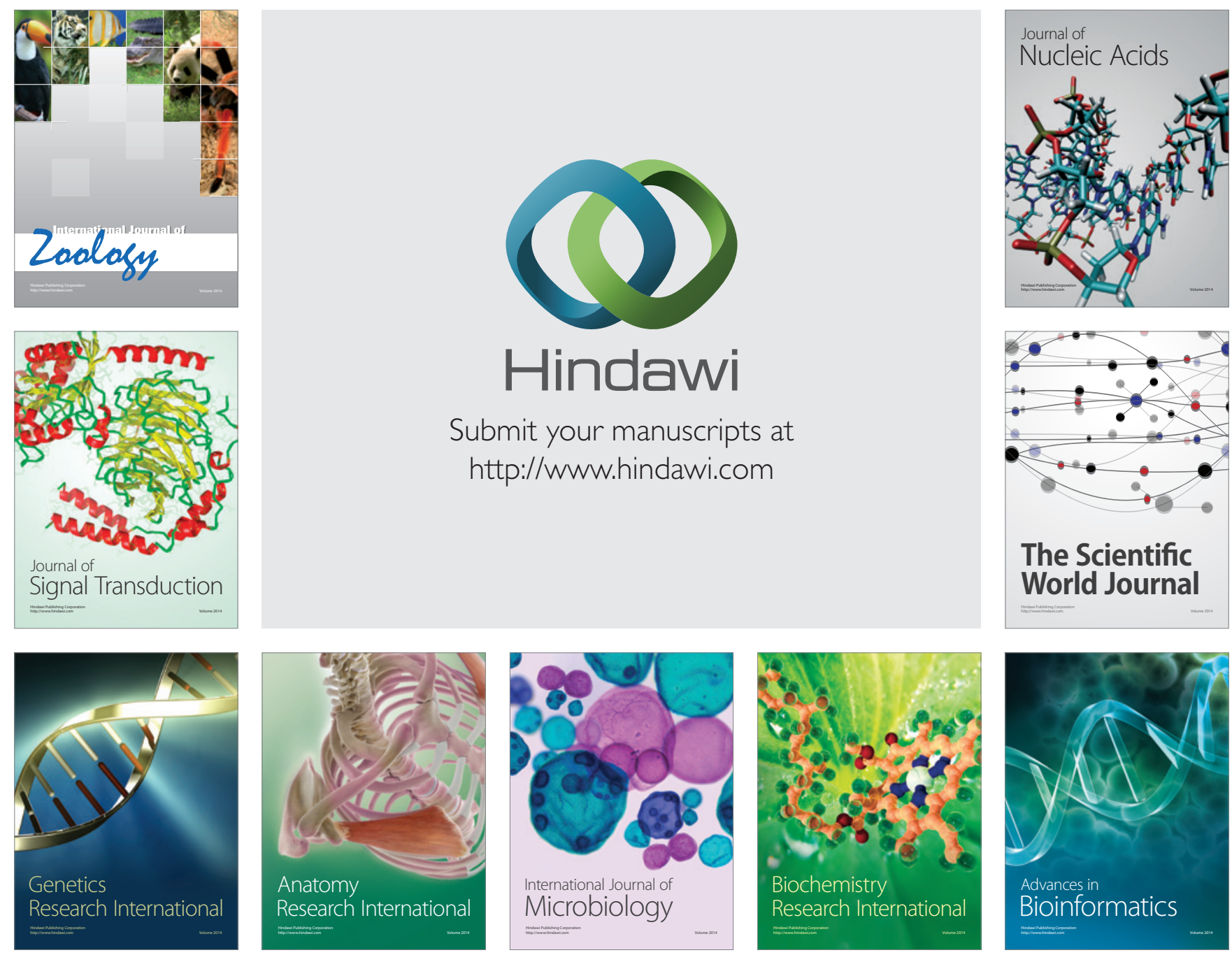

The Scientific World Journal
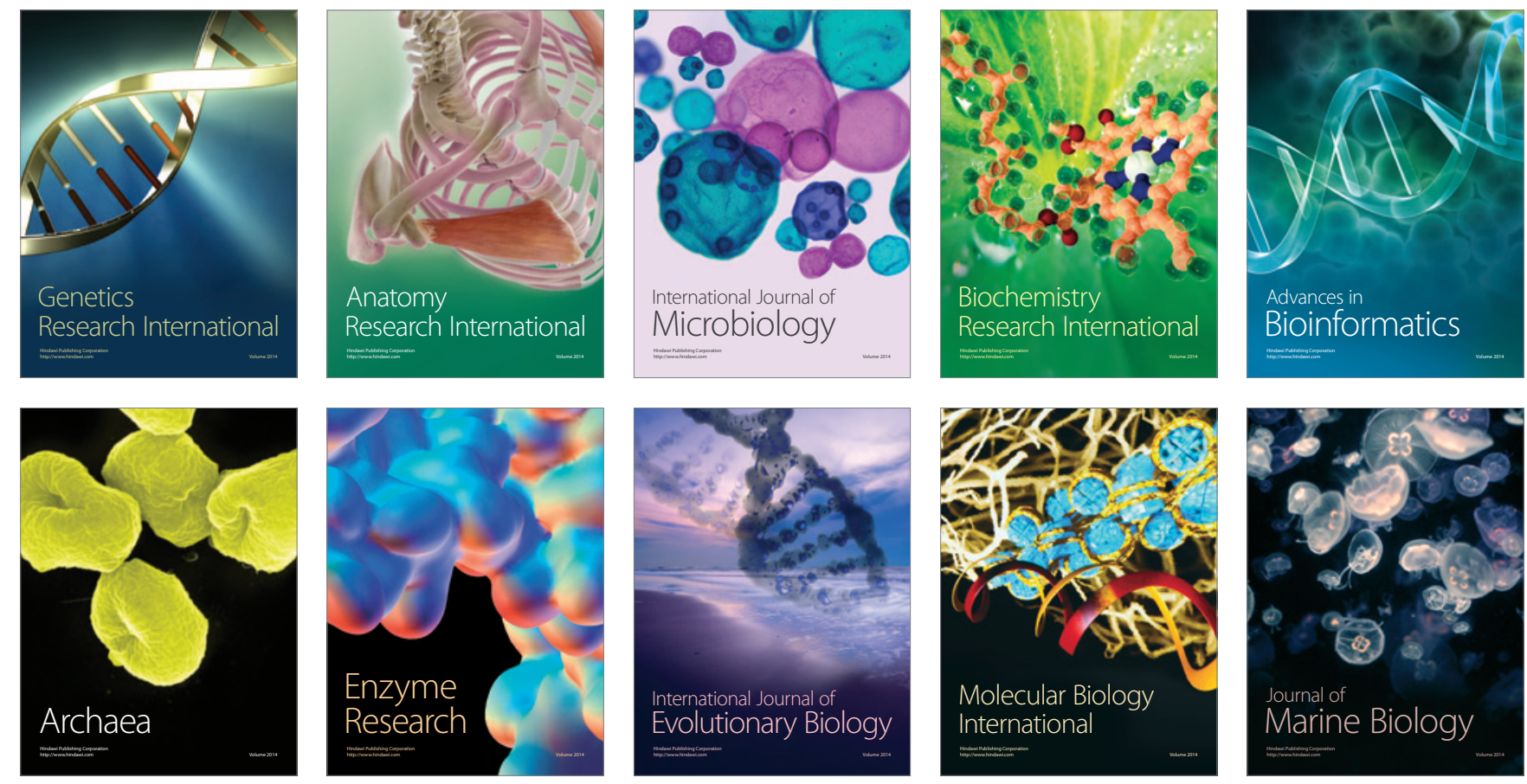